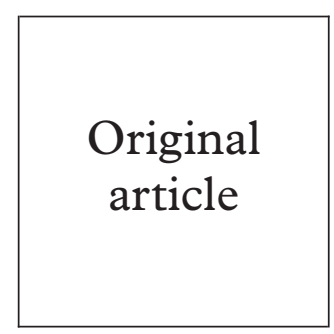

\title{
Sociodemography of genital Chlamydia trachomatis in Coventry, UK, 1992-6
}

\author{
A J Winter, P Sriskandabalan, A A H Wade, C Cummins, P Barker
}

Objective: To describe the sociodemographic and geographic risk factors for incident Chlamydia trachomatis genital infection.

Design: Cross sectional retrospective study of cases diagnosed in local genitourinary clinics.

Setting: Coventry, West Midlands, from 1992 to 1996.

Subjects: 582 female and 620 male Coventry residents aged 15-64 years diagnosed with one or more episodes of genital Chlamydia trachomatis infection by enzyme immunoassay. Subjects were assigned a Townsend deprivation score based on residence. The denominator population aged 15-64 years was derived from 1991 census data.

Results: The mean annual incidence of genital chlamydia was 151 episodes (95\% CI 140-163) per 100000 population in men and 138 episodes (95\% CI 128-149) per 100000 population in women. Highest subgroup incidence was observed in 15-19 year old black women (2367 (95\% CI 1370-4560) per 100 000), and 20-24 year old black men (1951 (95\% CI 1158-3220) per 100 000). In univariate analyses, the most important risk factor for chlamydia infection in males was being black (incidence 1377 (95\% CI 1137-1652) per 100000 for black $v 133$ (95\% CI $122-145)$ per 100000 for white; RR 10.4, $\mathrm{p}<0.0001$ ) and for women was young age (incidence 475 (95\% CI 415-540) per 100000 for age group 15-19 years $v 52$ (95\% CI 45-60) per 100000 for age group 25-64 years; RR 9.1, $\mathrm{p}<0.0001)$. In Poisson regression models of first episodes of genital chlamydia, for both males and females the effect of ethnic group could not be fully explained by socioeconomic confounding. There were significant interactions between age and ethnic group for both sexes and between age and level of deprivation for men. Geographical analysis revealed a high incidence of genital chlamydia in estates on the edge of the city as well as the urban core.

Conclusions: There is a complex interaction between geographical location, age, ethnic group, and social deprivation on the risk of acquiring genital Chlamydia trachomatis in Coventry. Better population based data are needed.

(Sex Transm Inf 2000;76:103-109)

Keywords: chlamydia infections; epidemiology; ethnicity; deprivation

Department of

Genitourinary

Medicine, Walsgrave

NHS Trust, Coventry

A J Winter

P Sriskandabalan

A A H Wade

Department of Public

Health and

Epidemiology,

University of

Birmingham

C Cummins

Department of Public

Health, Coventry

Health Authority,

Coventry

P Barker

Correspondence to:

Dr Andrew J Winter,

Department of

Genitourinary Medicine,

Glasgow Royal Infirmary,

16 Alexandra Parade,

Glasgow G31 2ER email:

andy_winter@talk21.com

Accepted for publication

11 January 2000

\section{Introduction}

Chlamydia trachomatis is the commonest bacterial sexually transmitted infection in the United Kingdom: 38632 cases were reported by genitourinary clinics in England in 1997, 20\% more than in $1996 .{ }^{1}$ Late sequelae include pelvic inflammatory disease, tubal infertility, and ectopic pregnancy. ${ }^{2}$ In spite of its importance there are few data on geographic and demographic risk factors for genital $C$ trachomatis infection in the United Kingdom..$^{3-5}$ A major problem is that there is a huge reservoir of undiagnosed asymptomatic disease. There have been no large scale population based prevalence surveys in the United Kingdom although a national screening programme to detect genital $C$ trachomatis is now being piloted in two sites. ${ }^{6}$ This contrasts with certain regions of the United States ${ }^{78}$ and Sweden 9 which have adopted a more aggressive approach to chlamydia screening. Reported prevalence in the United Kingdom varies according to setting, with genital $C$ trachomatis found in $2.6 \%-12 \%$ of women attending an urban general practice for cervical smear testing $^{10-12}$ and up to $28 \%$ of those attending for termination of pregnancy. ${ }^{13}$ These studies are all in selected populations. Data on male infec- tion are sparse and limited to genitourinary clinic attenders. ${ }^{414}$

Two recent studies have investigated the geographic, demographic, and ethnic distribution of Neisseria gonorrhoea infection in London and Leeds. ${ }^{15} 16$ Given the lack of information regarding genital $C$ trachomatis, we investigated the geographic, demographic, and ethnic distribution of 1340 genital $C$ trachomatis episodes diagnosed in residents of Coventry for the 5 year period from 1 January 1992 to 31 December 1996 using methods derived from these earlier studies. We wanted to identify geographical areas of high incidence to inform health education resource allocation and provide a baseline by which we could measure subsequent interventions. We were able to demonstrate clear differences in the incidence of genital $C$ trachomatis according to age, ethnic group, socioeconomic stratum, and geographic residence.

\section{Methods}

SETTING

Coventry is an industrial city in the West Midlands with a population of around 300000 . It has a high unemployment rate $(12.3 \%$ in the 1991 census) and many residents from ethnic minorities. Among those aged 15-64 years, 
ethnic Asian groups constituted 9.3\% and black ethnic groups $1.7 \%$ of the population in the 1991 census.

The only genitourinary medicine (GUM) clinic in Coventry (clinic A) is at an accessible city centre site and sees about 4000 new episodes of sexual infection each year. A single public health laboratory processes all $C$ trachomatis tests from this GUM clinic, and all other community and acute sources within the city. Five other GUM clinics lie within 20 miles of Coventry: three smaller clinics (B, C, D) are located in nearby towns and two large clinics $(\mathrm{E}$ and $F$ ) serve the neighbouring conurbation of Birmingham (see fig 1).

CASE FINDING, DATA HANDLING, AND DENOMINATOR POPULATION

We included as $C$ trachomatis episodes all patients seen in Coventry GUM clinic between 1 January 1992 and 31 December 1996 who were aged between 15 and 64 years, were resident in Coventry (as defined by the 1991 census), and who had genital $C$ trachomatis infection detected by confirmed enzyme immunoassay. Neighbouring GUM clinics agreed to provide limited data on probable Coventry residents attending with $C$ trachomatis episodes in the same time period (except clinic $\mathrm{F}$ which could only search records from 1 January 1994). Because the full post code was not released we could not confirm that all these cases were in fact resident within the Coventry health authority area nor could we ascribe them to an electoral ward. These few cases were thus excluded. In all clinics, cases were found by a retrospective search of the patient database for the computer codes for uncomplicated and complicated genital chlamydia. Repeat diagnoses within one month were excluded and subsequent episodes flagged as genuine repeats. In Coventry GUM clinic only, the data set was validated by matching cases against laboratory computer records of positive $C$ trachomatis tests in GUM attenders obtained from July 1993 onwards. Additional cases missed in the original coding were also added to the dataset. The laboratory also provided aggregate data for positive $C$ trachomatis results obtained in Coventry residents from all nonGUM clinic sources, but personal demographic information was not released so we could not ascertain if any of these cases had attended the GUM service.

We extracted demographic data onto a relational database (Microsoft Access 4.0) to allow matching of postcodes to electoral ward. Missing postcodes were supplied from the 1996 UK postcode directory where possible. ${ }^{17}$ All data were then anonymised. Sexual orientation could not be ascertained reliably, but homosexually acquired $C$ trachomatis accounts for under $2 \%$ of $C$ trachomatis infection nationally. ${ }^{1}$

Figures for ethnic, age, and ward specific populations were obtained from Coventry Health Authority and those not included as cases were deemed to be free of genital $C$ trachomatis. The basic denominator population was made up of 187690 Coventry residents aged 15-64 recorded in the 1991 census. For "other metropolitan areas" like Coventry, overall underenumeration was estimated at less than $7 \%$ in the 1991 census, although it was likely to be higher in young men. ${ }^{18}$ Because of the detailed subgroup analysis we used raw census data as it was impossible to obtain adjustment factors for each subgroup by ward.

\section{ANALYSIS}

Crude annualised incidence rates for first and repeat episodes of $C$ trachomatis were expressed per 100000 population aged 15-64 years. Case numbers for the whole 5 year period were aggregated and the population at risk assumed to be five times the raw census population for the subgroup in question. Risk factors were deliberately kept simple to minimise the complexity of the regression models. Age was banded into three groups (15-19 years, 20-24 years, and 25-64 years). Ethnic group was assigned by the booking clerk into a 1991 census category depending on the patient's stated ethnicity in a registration questionnaire. For the purposes of this study, ethnic groups were amalgamated and defined as white; black (black Caribbean, black African, and black other); or other (including Indian, Pakistani, Bangladeshi, Chinese, Asian, or other).

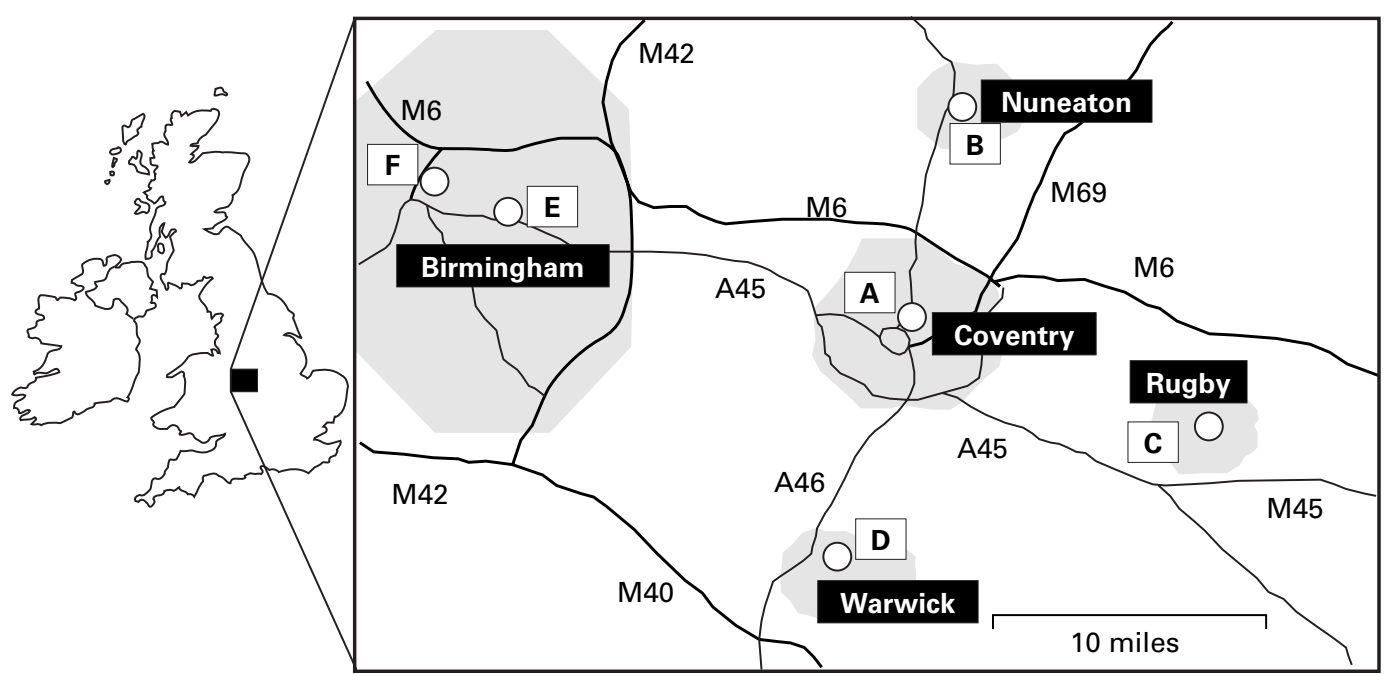

Figure 1 Map of the West Midlands, showing location of major towns and respective GUM clinics (O). The approximate boundary of Coventry is shaded. 
Table 1 Annual incidence of genital Chlamydia trachomatis episodes in Coventry residents attending local genitourinary clinics

\begin{tabular}{llllll}
\hline & \multicolumn{2}{c}{ Males aged } & 15-64 (population 93 807*) & & \multicolumn{2}{c}{ Females aged } & 15-64 (population 93 883*) \\
\cline { 2 - 3 } \cline { 6 - 6 } Year & Casest & $\begin{array}{c}\text { Incidence per 100 000 } \\
\text { (95\% confidence limit) }\end{array}$ & & Casest & $\begin{array}{c}\text { Incidence per 100 000 } \\
\text { (95\% confidence limit) }\end{array}$ \\
\hline 1992 & 178 & $190(163-220)$ & & 131 & $141(117-165)$ \\
1993 & 181 & $193(166-223)$ & & 108 & $150(95-139)$ \\
1994 & 127 & $135(113-162)$ & & 164 & $175(149-204)$ \\
1995 & 106 & $113(93-137)$ & & 122 & $130(108-156)$ \\
1996 & 117 & $125(104-150)$ & & 122 & $130(108-156)$ \\
Overall & 709 & $151(140-163)$ & & 647 & $138(128-149)$ \\
\hline
\end{tabular}

^Population assumed constant for years 1992-6.

†Excludes 14 cases known to be Coventry residents attending outlying clinics for whom the date of attendance is unknown.

Patients were assigned to one of three levels of deprivation (low, moderate, or high) depending on their area of residence, as individual socioeconomic data were not collected. We used the Townsend score to measure deprivation, ranking the 18 electoral wards in Coventry into three groups of six based on the 1991 census scores. The Townsend score for a ward reflects the average level of overcrowding, unemployment, car ownership, and housing tenure. ${ }^{19}$ Thus, our adjustment for deprivation is based on an ecological measure of deprivation of area of residence rather than an individual measure. Multivariate Poisson regression models were generated with STATA (v 5.0, Austin, TX, USA). Separate models were generated for male rates and for female rates. The main effects, age group (aged 15-19, 20-24, or 25-64), deprivation level (low, moderate, or high), and ethnic group (white, black, or other) were fitted. The impact of every possible two way interaction term upon this model was considered. Two way interaction terms were then added in an order that took account of their impact singly upon the main effects model, and resultant models were tested sequentially against the previous (nested) model until a good fit was achieved and no further statistically significant improvements in

Table 2 Incidence rates for all episodes of genital Chlamydia trachomatis in Coventry residents 1992-6 according to demographic risk factors

\begin{tabular}{|c|c|c|c|c|}
\hline & Cases & $\begin{array}{l}\text { Population at risk } \\
1992-6^{\star}\end{array}$ & $\begin{array}{l}\text { Annualised crude } \\
\text { incidence (95\% CI) (per } \\
100000 \text { aged 15-64) }\end{array}$ & $\begin{array}{l}\text { Crude rate ratio } \\
\text { within group }\end{array}$ \\
\hline \multicolumn{5}{|l|}{ Males } \\
\hline \multicolumn{5}{|l|}{ Age (years) } \\
\hline $15-19$ & 66 & 48805 & $135(102-172)$ & 1.2 \\
\hline $20-24$ & 236 & 61140 & $386(338-438)$ & 3.5 \\
\hline $25-64$ & 396 & 359110 & $110(100-121)$ & 1.0 \\
\hline \multicolumn{5}{|l|}{ Ethnic group } \\
\hline white & 547 & 411435 & $133(122-145)$ & 1.0 \\
\hline black & 114 & 8280 & $1377(1137-1652)$ & 10.4 \\
\hline other & 37 & 49340 & $75(54-105)$ & 0.6 \\
\hline \multicolumn{5}{|l|}{ Deprivation } \\
\hline low & 141 & 151245 & $93(78-110)$ & 1.0 \\
\hline moderate & 242 & 157590 & $154(134-174)$ & 1.7 \\
\hline high & 315 & 160220 & $197(176-220)$ & 2.1 \\
\hline \multicolumn{5}{|l|}{ Females } \\
\hline \multicolumn{5}{|l|}{ Age (years) } \\
\hline $15-19$ & 225 & 47410 & $475(415-540)$ & 9.1 \\
\hline $20-24$ & 230 & 61445 & $374(327-426)$ & 7.2 \\
\hline 25-64 & 187 & 360560 & $52(45-60)$ & 1.0 \\
\hline \multicolumn{5}{|l|}{ Ethnic group } \\
\hline white & 587 & 412365 & $142(131-155)$ & 1.0 \\
\hline black & 38 & 7855 & $484(343-663)$ & 3.4 \\
\hline other & 17 & 49195 & $35(20-55)$ & 0.2 \\
\hline \multicolumn{5}{|l|}{ Deprivation } \\
\hline low & 172 & 149850 & $115(99-134)$ & 1.0 \\
\hline moderate & 199 & 155370 & $128(111-147)$ & 1.1 \\
\hline high & 271 & 164195 & $165(146-186)$ & 1.4 \\
\hline
\end{tabular}

the model were made. A rate ratio (RR) of 1.0 was assigned to those who were white, lived in an affluent area, and were aged between 25 and 64 years. Exact $95 \%$ confidence limits for proportions were calculated using ARCUS PROSTAT v 3.0 or EPI-INFO v 6.0. For geographical analysis we used MAP INFO PROFESSIONAL v 5.0 to plot all episode $C$ trachomatis incidence at the level of postcode district aggregating data from all 5 years, and calculated $C$ trachomatis episode rates for each electoral ward.

\section{Results}

\section{CASE DETECTION}

During the 5 year period a total of $1370 C$ trachomatis episodes were diagnosed in 1231 Coventry residents between 15 and 64 years of age attending GUM clinics A-F. Of these, 20 $C$ trachomatis episodes (1.5\%) in 19 Coventry residents were diagnosed in outlying clinics $\mathrm{B}-\mathrm{F}$ and these cases were therefore excluded. Ten episodes $(0.7 \%)$ presenting to Coventry GUM clinic were excluded because no ethnic status was recorded or the patients were of no fixed abode.

Aggregate data from Coventry laboratory computer records were available from July 1993 to December 1996. During that time, genital $C$ trachomatis was diagnosed in 275 Coventry residents attending local general practitioners, family planning clinics, or hospitals. Coventry GUM clinic diagnosed 827 $C$ trachomatis episodes in Coventry residents over the same period, giving a maximum number of 1102 diagnosed $C$ trachomatis cases in Coventry. It was not possible to cross match cases diagnosed in GUM with cases diagnosed in the laboratory as personal identifiers were not available, although we anticipate that many cases diagnosed outside GUM would have attended GUM clinics for follow up according to local protocol. Even assuming none of the cases diagnosed outside the GUM service attended the GUM clinic, at least $75 \%$ $(827 / 1102)$ of $C$ trachomatis episodes were diagnosed from within the GUM service and thus would be included in the study over this 3.5 year period.

\section{EPISODE INCIDENCE}

The final data set consisted of 1340 episodes (642 females, 698 males) in 1202 patients (582 females; 620 males) attending clinic A. Mean annual episode incidence was for males 151 (95\% CI 140-163) per 100000 population aged 15-64 years and for females 138 (95\% CI 128-149) per 100000 population aged 15-64 years. Table 1 shows the variation in annual $C$ trachomatis episode incidence during the study period.

The overall rate conceals large differences in geographic and age and ethnic specific distribution of genital $C$ trachomatis. Table 2 shows the crude incidence of all episodes of genital $C$ trachomatis in each demographic subgroup. In univariate analyses, the most important risk factor for males was being black (incidence 1377 (95\% CI 1137-1652) per 100000 for black $v 133$ (95\% CI 122-145) per 100000 for white; rate ratio $10.4, \mathrm{p}<0.0001$ by $\chi^{2}$ test) and 


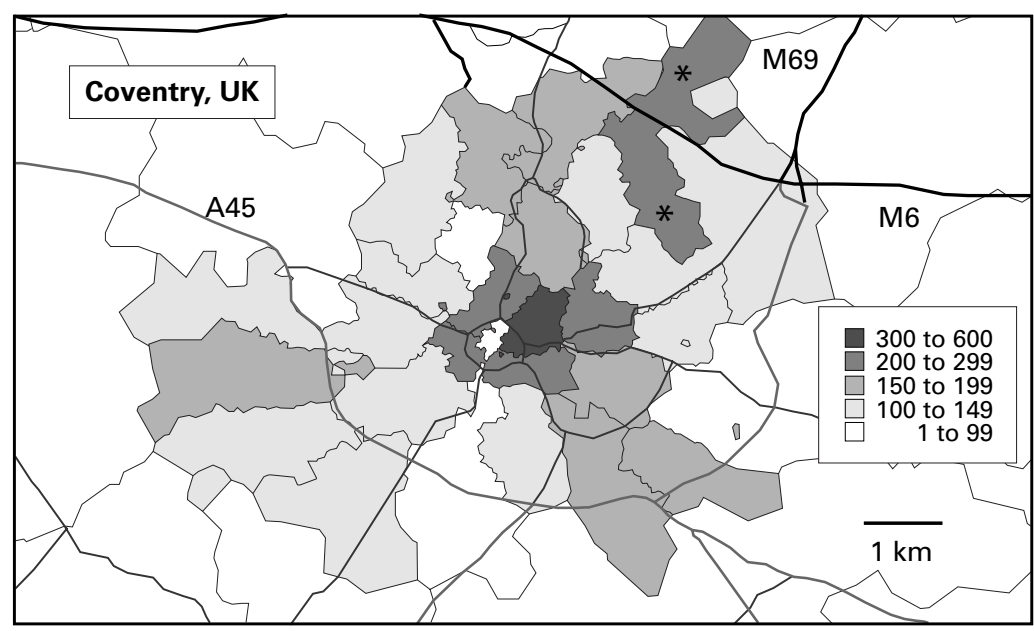

Figure 2 Map of Coventry showing annualised incidence of all genital chlamydia episodes (1992-6) per 100000 population aged 15-64, with arbitrary divisions. Note that incidence is relatively high both in the urban core and in estates on the edge of the city $\left(^{*}\right)$. Produced with MAPINFO Professional v 5.0 (1998).

for women was young age (incidence $475(95 \%$ CI 415-540) per 100000 for age group 15-19 years $v 52(95 \%$ CI 45-60) per 100000 for age group 25-64 years; rate ratio 9.1, $\mathrm{p}<0.0001$ by $\chi^{2}$ test). The highest all episode incidences were observed in 15-19 years old black females living in the most deprived third of the city (2637 (95\% CI 1370-4560) per 100 000) and 20-24 years old black men in the same area (1951 (95\% CI 1158-3220) per 100 000). The most affected electoral ward (St Michael's) had an incidence of 417 (95\% CI 361-481) per 100000 population aged $15-64$, some 2.7 times that in the next most affected ward (other data not shown). Figure 2 shows all episode incidence of $C$ trachomatis mapped by postcode district, showing that a high incidence of genital $C$ trachomatis is found both in the urban core and in estates on the edge of the city.
REPEAT INFECTIONS

Among the 1202 patients, 114 (9.5\%) attended with one or more subsequent episodes of genital $C$ trachomatis at least one month after the first episode. The proportion of these repeat infections did not vary significantly according to age group, area of residence, deprivation, or sex. However, significantly more black men than white men sustained reinfections $(19 / 62$ $(23.5 \%)$ black $v 38 / 465$ white $(7.6 \%) ; \mathrm{p}<0.001$ by $\chi^{2}$ ).

POISSON REGRESSION MODELS OF FIRST EPISODES OF GENITAL CHLAMYDIA

Tables 3 and 4 show the incidence for first episode genital $C$ trachomatis with unadjusted rate ratios for each of the defined subgroups, and the estimated rate ratios derived from Poisson regression models constructed for each sex. When constructing the regression models all repeat infections were excluded as the cases would not be independent. The rate ratios therefore represent differences in incidence of first presentation with genital $C$ trachomatis. Details of the goodness of fit and interaction coefficients are available from the authors.

The final Poisson regression model for men included main effects for age group, ethnic group, and level of deprivation (as judged by area of residence), an interaction term between age and ethnic group, and an interaction term between ethnic group and level of deprivation on the rate ratio scale. That is, the effect of both age and deprivation level depended on a man's ethnic group. Table 3 gives rate ratios for men estimated from the model, with white men aged 25-64 living in the least deprived areas as the baseline category. Black ethnic group is independently associated with high chlamydia

Table 3 Estimated rate ratios derived from Poisson regression model of first episodes of genital Chlamydia trachomatis infection, Coventry residents 1992-96, males

\begin{tabular}{|c|c|c|c|c|c|c|c|c|c|}
\hline $\begin{array}{l}\text { Age } \\
\text { band } \\
\text { (years) }\end{array}$ & $\begin{array}{l}\text { Ethnic } \\
\text { groupy }\end{array}$ & $\begin{array}{l}\text { Deprivation } \\
\text { level }\end{array}$ & Episodes & $\begin{array}{l}\text { Population } \\
\text { 1992-6 }\end{array}$ & $\begin{array}{l}\text { Incidence (per } \\
100000)\end{array}$ & $95 \% C I$ & $\begin{array}{l}\text { Unadjusted } \\
\text { rate ratio }\end{array}$ & $\begin{array}{l}\text { Adjusted } \\
\text { rate ratio* }\end{array}$ & $\begin{array}{l}\text { Confidence } \\
\text { interval }\end{array}$ \\
\hline \multirow[t]{9}{*}{$15-19$} & \multirow[t]{3}{*}{ white } & low & 12 & 14015 & 86 & $(44-149)$ & 1.3 & 1.4 & $(1.0-1.9)$ \\
\hline & & moderate & 16 & 13650 & 117 & $(67-190)$ & 1.8 & 2.2 & $(1.5-3.2)$ \\
\hline & & high & 20 & 12515 & 160 & $(98-247)$ & 2.5 & 2.5 & $(1.7-3.6)$ \\
\hline & \multirow[t]{3}{*}{ black } & low & 0 & 205 & 0 & $(0-1780)$ & 0.0 & 3.0 & $(0.8-11.6)$ \\
\hline & & moderate & 2 & 235 & 851 & $(103-3040)$ & 13.3 & 9.5 & $(3.8-23.6)$ \\
\hline & & high & 4 & 395 & 1013 & $(277-2572)$ & 15.8 & 18.3 & $(7.9-42.2)$ \\
\hline & \multirow[t]{3}{*}{ other } & low & 1 & 1105 & 90 & $(23-503)$ & 1.4 & 0.9 & $(0.2-3.2)$ \\
\hline & & moderate & 11 & 2000 & 50 & $(27-98)$ & 0.8 & 0.6 & $(0.2-2.3)$ \\
\hline & & high & 1 & 4685 & 21 & $(0-120)$ & 0.3 & 0.6 & $(0.2-1.9)$ \\
\hline \multirow[t]{9}{*}{$20-24$} & \multirow[t]{3}{*}{ white } & low & 36 & 16145 & 223 & $(156-309)$ & 3.5 & 4.2 & $(3.5-5.1)$ \\
\hline & & moderate & 63 & 17165 & 367 & $(282-469)$ & 5.7 & 6.4 & $(4.8-8.6)$ \\
\hline & & high & 88 & 18450 & 475 & $(385-588)$ & 7.4 & 7.3 & $(5.5-9.8)$ \\
\hline & \multirow[t]{3}{*}{ black } & low & 2 & 205 & 976 & $(118-3480)$ & 15.3 & 3.5 & $(1.0-12.3)$ \\
\hline & & moderate & 3 & 450 & 667 & $(138-1936)$ & 10.4 & 11.1 & $(5.6-22.3)$ \\
\hline & & high & 9 & 820 & 1098 & (503-2073) & 17.2 & 21.6 & $(12.2-38.3)$ \\
\hline & \multirow[t]{3}{*}{ other } & low & 1 & 1385 & 72 & $(2-401)$ & 1.1 & 3.4 & $(1.5-8.0)$ \\
\hline & & moderate & 5 & 2010 & 249 & $(80-580)$ & 3.9 & 2.5 & $(1.1-5.7)$ \\
\hline & & high & 6 & 4420 & 136 & $(50-295)$ & 2.1 & 2.3 & $(1.2-4.6)$ \\
\hline \multirow[t]{9}{*}{$25-64$} & \multirow[t]{3}{*}{ white } & low & 71 & 111735 & 64 & $(50-80)$ & referent & referent & referent \\
\hline & & moderate & 104 & 110075 & 94 & $(78-115)$ & 1.5 & 1.5 & $(1.2-1.9)$ \\
\hline & & high & 93 & 97595 & 95 & $(77-117)$ & 1.5 & 1.7 & $(1.4-2.2)$ \\
\hline & \multirow[t]{3}{*}{ black } & low & 1 & 940 & 106 & $(3-591)$ & 1.7 & 3.9 & $(1.2-12.5)$ \\
\hline & & moderate & 14 & 1970 & 711 & $(389-1190)$ & 11.1 & 12.5 & $(7.5-20.7)$ \\
\hline & & high & 46 & 3060 & 1503 & $\begin{array}{l}(1102- \\
2000)\end{array}$ & 23.5 & 24.2 & $(17.1-34.1)$ \\
\hline & \multirow[t]{3}{*}{ other } & low & 6 & 5510 & 109 & $(40-240)$ & 1.7 & 1.4 & $(0.6-3.0)$ \\
\hline & & moderate & 4 & 10035 & 40 & $(11-102)$ & 0.6 & 1.0 & $(0.5-2.1)$ \\
\hline & & high & 11 & 18190 & 60 & $(30-108)$ & 0.9 & 0.9 & $(0.5-1.7)$ \\
\hline
\end{tabular}

*Adjusted by Poisson regression with white, aged 25-64 and lowest deprivation as baseline.

Main effects plus terms for interaction between ethnic group and age and ethnic group and deprivation level. 
Table 4 Estimated rate ratios derived from Poisson regression model of first episodes of genital Chlamydia trachomatis infection, Coventry residents 1992-96, females

\begin{tabular}{|c|c|c|c|c|c|c|c|c|c|}
\hline $\begin{array}{l}\text { Age } \\
\text { band (y) }\end{array}$ & $\begin{array}{l}\text { Ethnic } \\
\text { group }\end{array}$ & $\begin{array}{l}\text { Deprivation } \\
\text { level }\end{array}$ & Episodes & $\begin{array}{l}\text { Population } \\
1992-6\end{array}$ & $\begin{array}{l}\text { Incidence } \\
\text { (per } 100 \text { 000) }\end{array}$ & $95 \% C I$ & $\begin{array}{l}\text { Unadjusted } \\
\text { rate ratio }\end{array}$ & $\begin{array}{l}\text { Adjusted } \\
\text { rate ratio* }\end{array}$ & $95 \% C I$ \\
\hline \multirow[t]{9}{*}{$15-19$} & \multirow[t]{3}{*}{ white } & low & 46 & 13415 & 343 & $(251-457)$ & 7.5 & 9.0 & $(7.3-11.1)$ \\
\hline & & moderate & 56 & 12560 & 446 & $(337-579)$ & 9.7 & 10.4 & $(7.7-14.1)$ \\
\hline & & high & 79 & 13010 & 607 & $(481-756)$ & 13.2 & 12.3 & $(9.2-16.5)$ \\
\hline & \multirow[t]{3}{*}{ black } & low & 1 & 180 & 556 & $(14-3056)$ & 12.1 & 28.1 & $(15.9-49.4)$ \\
\hline & & moderate & 2 & 220 & 909 & $(110-3245)$ & 19.8 & 32.4 & $(17.7-59.2)$ \\
\hline & & high & 10 & 455 & 2198 & $\begin{array}{l}(1060- \\
4005)\end{array}$ & 47.8 & 38.3 & $(21.3-69.1)$ \\
\hline & \multirow[t]{3}{*}{ other } & low & 0 & 1100 & 0 & $(0-330)$ & 0.0 & 0.5 & $(0.1-1.9)$ \\
\hline & & moderate & 0 & 2085 & 0 & $(0-180)$ & 0.0 & 0.6 & $(0.1-2.3)$ \\
\hline & & high & 2 & 4385 & 46 & $(6-165)$ & 1.0 & 0.7 & $(0.2-2.7)$ \\
\hline \multirow[t]{9}{*}{$20-24$} & \multirow[t]{3}{*}{ white } & low & 51 & 14770 & 345 & $(257-454)$ & 7.5 & 7.0 & $(5.7-8.6)$ \\
\hline & & moderate & 65 & 16485 & 394 & $(298-492)$ & 8.6 & 8.1 & $(6.0-10.8)$ \\
\hline & & high & 76 & 20990 & 362 & $(285-453)$ & 7.9 & 9.6 & $(7.2-12.7)$ \\
\hline & \multirow[t]{3}{*}{ black } & low & 0 & 140 & 0 & $(0-2600)$ & 0.0 & 10.5 & $(5.1-21.3)$ \\
\hline & & moderate & 3 & 370 & 811 & $(168-2351)$ & 17.6 & 12.1 & $(5.8-25.3)$ \\
\hline & & high & 5 & 860 & 581 & $(190-1352)$ & 12.6 & 14.3 & $(6.9-29.5)$ \\
\hline & \multirow[t]{3}{*}{ other } & low & 4 & 1110 & 360 & $(98-920)$ & 7.8 & 2.3 & $(1.2-4.4)$ \\
\hline & & moderate & 2 & 2000 & 100 & $(12-361)$ & 2.2 & 2.7 & $(1.4-5.2)$ \\
\hline & & high & 4 & 4720 & 85 & $(23-217)$ & 1.8 & 3.2 & $(1.6-6.1)$ \\
\hline \multirow[t]{9}{*}{$25-64$} & \multirow[t]{3}{*}{ white } & low & 52 & 113145 & 46 & $(34-60)$ & referent & referent & referent \\
\hline & & moderate & 49 & 109880 & 45 & $(33-59)$ & 1.0 & 1.2 & $(0.9-1.4)$ \\
\hline & & high & 63 & 98110 & 64 & $(49-82)$ & 1.4 & 1.4 & $(1.1-1.7)$ \\
\hline & \multirow[t]{3}{*}{ black } & low & 0 & 885 & 0 & $(0-420)$ & 0.0 & 2.6 & $(1.3-5.3)$ \\
\hline & & moderate & 2 & 1870 & 107 & $(13-386)$ & 2.3 & 3.0 & $(1.4-6.3)$ \\
\hline & & high & 6 & 2875 & 209 & $(77-454)$ & 4.5 & 3.6 & $(1.7-7.4)$ \\
\hline & \multirow[t]{3}{*}{ other } & low & 0 & 5105 & 0 & $(0-70)$ & 0.0 & 0.2 & $(0.1-0.6)$ \\
\hline & & moderate & 4 & 9900 & 40 & $(11-103)$ & 0.9 & 0.3 & $(0.1-0.7)$ \\
\hline & & high & 0 & 18790 & 0 & $(0-20)$ & 0.0 & 0.3 & $(0.1-0.8)$ \\
\hline
\end{tabular}

*Adjusted by Poisson regression with white, aged 25-64 and lowest deprivation as baseline.

Main effects plus term for interaction between age and ethnic group.

incidence in males, even more so at age $20-24$ and in the most deprived areas.

The final Poisson regression model for women included main effects for age group, ethnic group, and level of deprivation (as judged by area of residence), and an interaction term between age and ethnic group on the rate ratio scale - that is, the effect of age depended upon a woman's ethnic group. Table 4 gives rate ratios for women estimated from the model, with white women aged 25-64 living in the least deprived areas as the baseline category. Black ethnic group is independently associated with high chlamydia incidence in women, even more so at a young age.

\section{Discussion}

Within the limitations of a retrospective, clinic based study we have shown large differences in genital $C$ trachomatis episode rates which we believe cannot be explained by case ascertainment bias alone. Notable risk factors include young age (15-19 years) for female infection, and black ethnic group for male infection. There is undoubtedly a complex interaction between sex, geographical location, age, ethnic group, and social deprivation on the risk of acquiring genital $C$ trachomatis.

Several methodological weaknesses are apparent. Firstly, we will have missed cases because we included only those presenting to GUM clinics for testing. We had insufficient data for those patients diagnosed outside the GUM clinic setting to permit demographic analysis, but these constitute under $25 \%$ of all locally diagnosed cases. More important is the unknown number of cases of genital $C$ trachomatis in Coventry which were never diagnosed during the study period. Thus, our results must be interpreted with care. Secondly, the study predates implementation of sensitive nucleic acid amplification methods for $C$ trachomatis diagnosis. ${ }^{20}$ These were unavailable in Coventry and many other parts of the United Kingdom at the time of the study. We have therefore missed a proportion of genuine episodes of genital $C$ trachomatis among those tested in the GUM clinic. Thirdly, deprivation was examined as a function of geographical residence rather than at the level of the individual. Individual measures of deprivation are not routinely collected in UK GUM clinics, or indeed in many other healthcare settings. Even should such data be collected, it would have been difficult to relate to an appropriate denominator. A consequence of our method is that there may be residual confounding by unmeasured socioeconomic factors in the multivariable models. In mitigation, markers for local social disintegration, such as the level of violent crime per unit population, have been found useful as predictive markers for sexual infections ${ }^{21}$; thus, both individual and local social deprivation should ideally be considered. Finally, we have no information about past infection with $C$ trachomatis in this population. One study from Sweden reported a cervical $C$ trachomatis prevalence of $2.7 \%$ but found serological evidence of past infection in nearly $25 \%$ of those studied. ${ }^{22}$ This illustrates the huge reservoir of undiagnosed and untreated chlamydial infection. In spite of the unavoidable methodological problems in our study we believe that we have obtained useful data that will guide pilot studies of incidence in risk groups in the community. Such community based studies are already being piloted in other areas in the United Kingdom ${ }^{6}$ and in the United States. ${ }^{723}$

The highest age and sex specific incidence of genital $C$ trachomatis in Coventry based on this data set is slightly higher than that derived from 
statutory KC60 coding returns from GUM clinics for the whole of England and Wales (E\&W) in 1995 (females aged 16-19 years: 397 per 100000 (E\&W) v 475 per 100000 (Coventry, aged 15-19 years); males aged 20-24 years: 234 per $100000(\mathrm{E} \& W)$ v 386 per 100000 (Coventry)). ${ }^{5}$ The overall incidence for 1995 was similar in Coventry and in England and Wales as a whole (female 104 per 100000 aged $15-59$ years $(\mathrm{E} \& W) v 130$ per 100000 aged 15-64 years (Coventry); male 80 per 100000 aged 15-59 years (E\&W) v 106 per 100000 aged 15-64 years (Coventry)). Many studies in other populations have also shown that young women under 20 have the highest age and sex specific incidence of genital $C$ trachomatis. ${ }^{4}{ }^{74-27}$ Our findings are also consistent with data for $C$ trachomatis incidence from urban settings in other parts of the world. $^{728}$ The rates of $C$ trachomatis we observed are similar to those reported in a study of adolescents in San Francisco, who had a $C$ trachomatis incidence of 180 per 100000 in whites and 1673 per 100000 in blacks (relative risk for black race of 8.8).$^{28}$ However, with the advent of nucleic acid amplification tests, specific $C$ trachomatis incidence rates as high as $27 \%$ have been reported from some urban centres. ${ }^{29}$ Our data show that even in a smaller metropolitan town disease rates in some subgroups are typical of those in larger conurbations. Genital $C$ trachomatis appears to be widely distributed in all strata of society, ${ }^{4}$ in contrast with gonorrhoea, which appears to be much more limited to urban core areas. ${ }^{30}$

Studies of the influence of ethnicity on health outcomes are open to criticisms of bias and oversimplification. ${ }^{31}$ We recognise that broad ethnic divisions are a very crude marker for complex and subtle social, religious, and behavioural differences between the mix of people who make up a typical multiracial city, and that the census categories themselves fail to capture patients' self identity. ${ }^{32}$ Our study suggests that some members of the relatively small Afro-Caribbean community in Coventry may carry a disproportionate burden of genital $C$ trachomatis infection, but cannot address why. A similar pattern has been observed for genital infection with Neisseria gonorrhoea in both Leeds ${ }^{15}$ and inner London. ${ }^{16}$ We have unpublished data to show that the acquisition of genital warts in Coventry does not vary by ethnic group but is affected by social deprivation, ${ }^{33}$ suggesting that the undue burden of $C$ trachomatis in certain ethnic groups we observed is a real effect. As we found for male $C$ trachomatis infection, the effects of deprivation may act differently according to ethnic group: for example, in Birmingham, United Kingdom, a recent retrospective study of tuberculosis incidence showed that poverty adversely affects incidence of tuberculosis in white people but does not affect tuberculosis incidence of those of south Asian origin. ${ }^{34}$ In all such retrospective studies it is impossible to identify individual characteristics within a broad ethnic identity that predict high incidence of sexual infection, and fully allow for socioeconomic confounding. Our findings should encourage further prospective studies of the influence of religious and cultural beliefs on sexual behaviour in the United Kingdom. These need to be complemented by qualitative and quantitative investigations into the links between individual socioeconomic status, local social disintegration, and the acquisition of sexual infection.

We believe that geographical analysis of genital chlamydial infection is useful in demonstrating unsuspected areas of high disease incidence, which in this case included the city's outer estates. Other centres have also found case mapping of sexual infections useful. ${ }^{30}$ The highest $C$ trachomatis incidence in Coventry was found in St Michael's electoral ward, which is one of the most deprived areas in the West Midlands Region with an unemployment rate of over $25 \%$ and owner occupation of less than $40 \%$. Genital $C$ trachomatis incidence here is almost three times that of any other electoral ward in Coventry. Preliminary data show a similar excess of gonorrhoea incidence in $\mathrm{St}$ Michael's ward, with an annual episode rate of 142 gonorrhoea cases (95\% CI 111-182) per 100000 population aged 15-64 compared with a citywide rate of 37 (95\% CI 34-42) per 100 000. Possible explanations for this concentration of incident sexual infections may include its relatively high student population and local commercial sex work. Excessive census underenumeration may also be a factor, although this would have to be huge to account for the observed rate ratios. Such geographical information should inform sexual health promotion by local general practitioners and health educators.

In summary, we present worrying data which show a high incidence of genital $C$ trachomatis in certain population subgroups in Coventry similar to those seen in much larger urban areas. The United Kingdom urgently needs better population based prevalence data for genital chlamydial infection so that the hidden epidemic becomes plain for all to see.

We thank MD and AG of the information department of Coventry Health Authority for their enormous assistance in Coventry Health Authority for their enormous assistance in
summarising census data; JR for advice on MAPINFO; the follow-
ing genitourinary physicians for their assistance in data abstracing genitourinary physicians for their assistance in data abstrac-
tion: Mike Walzman (departments of genitourinary medicine at Nuneaton and Rugby), David White (department of sexual medicine, Heartlands Hospital, Birmingham), Dan Natin (department of genitourinary medicine, Warwick), and onathan Ross (Whittall Street Clinic, Birmingham); Andrea Roalfe, West Midlands Regional Office, for help with postcode conversion.

Presented in abstract form at the 12th International AIDS congress, Geneva, 1998 (abstract 23373). Contributors: AJW, PS, and AAHW conceived the study; AJW oversaw the study, performed data extraction and analysis and orete geographical analysis; CC performed the regression modelling and additional statistical analysis. All authors contributed to the final manuscript. No conflict of interest is declared by any author.

1 Hughes G, Simms I, Rogers PA, et al. New cases seen at genitourinary medicine clinics: England 1997. Commun Di Rep CDR Suppl 1998;8 (suppl 7):S1-11.

2 World Health Organisation Task Force on the Prevention and Management of Infertility. Tubal infertility: serologic relationship to past chlamydial and gonococcal infection. rex Transm to past chlamydia

3 Matondo P, Wall R, Morgan K, et al. Epidemiology of gonococcal and chlamydial infections in Harrow and Brent. coccal and chlamydial infections

4 Simms I, Catchpole M, Brugha R, et al. Epidemiology of genital Chlamydia trachomatis in England and Wales. Genitourin Med 1997;73:122-6. 
5 Department of Health. Chlamydia trachomatis: summary and conclusions of the Chief Medical Officer's Expert Advisory Group. London: DoH, 1998.

6 New report and pilot studies on Chlamydia. Commun Dis Rep CDR Wkly 1998;8:167-7.

7 Mertz KJ, McQuillan GM, Levine WC, et al. A pilot study of the prevalence of chlamydial infection in a national household survey. Sex Transm Dis 1998;25:225-8.

8 Scholes D, Stergarchis A, Heidrich FE, et al.. Prevention of pelvic inflammatory disease by screening for cervical
chlamydial infection. N Engl f Med 1996;334:1362-6.

9 Egger M, Low N, Smith GD, et al. Screening for chlamydial infections and the risk of ectopic pregnancy in a county in infections and the risk of ectopic pregnancy in a county

10 Grun L, Tassano-Smith J, Carder C, et al. Comparison of two methods of screening for genital chlamydial infection in women attending general practice: cross-sectional

11 Oakeshott P, Kerry S, Hay S, et al. Opportunistic screening for chlamydial infection at time of cervical smear testing in general practice: prevalence surve. BMF 1998;316:351-2

12 Smith JR, Murdoch J, Carrington D, et al. Prevalence of Chlamydia trachomatis infections in women having cervical smear tests. BM7 1991;302:82-4.

13 Wood SM, Muscat I. Screening and treatment to prevent post abortion chlamydial pelvic infection. Lancet 1989;ii: 928-9.

14 Zelin JM, Robinson AJ, Ridgway GL, et al. Chlamydial urethritis in heterosexual men attending a genitourinary medicine clinic: prevalence, symptoms, condom usage and partner change. Int f STD AIDS 1995;6:27-30.

15 Lacey CJN, Merrick DW, Bensley DC, et al.. Analysis of the sociodemography of gonorrhoea in Leeds, 1989-93. BMF 1997;314:1715-18.

16 Low N, Daker-White G, Barlow D, et al. Gonorrhoea in inner London: results of a cross-sectional study. BMF 1997;314:1719-23.

17 Royal Mail. Royal Mail postcode directory 1996. London: Royal Mail, 1996

18 Office of Population Censuses and Surveys GROS. 1991 Census User Guide 58: Undercoverage in Great Britain. London: OPCS, 1994.

19 Morris R, Carstairs V. Which deprivation index? A comparison of selected deprivation indexes. 7 Publ Health Med 1991;13:318-26.

20 Ridgway GL, Mumtaz G, Robinson AJ, et al. Comparison of the ligase chain reaction with cell culture for the diagnosis of Chlamydia trachomatis infection in women. 7 Clin Pathol of Chlamydia tracho
21 Wallace R, Wallace D. Socioeconomic determinants of health: community marginalisation and the diffusion of disease and disorder in the United States. BMF 1997;314 1341-5.

22 Jonsson M, Karlsson R, Persson K, et al. The influence of sexual and social factors on the risk of Chlamydia trachomatis infections: a population-based serologic study. Sex Transm Dis 1995;22:355-63.

23 Cohen DA, Nsuami M, Etame RB, et al. A school-based Chlamydia control program using DNA amplification technology. Pediatrics 1998;101:E1.

24 Acosta-Cazares B, Ruiz-Maya L, Escobedo de la Pena J. Prevalence and risk factors for Chlamydia trachomatis infection in low-income rural and suburban populations of Mexico. Sex Trans Dis 1996;23:283-8.

25 Van Duynhoven YT, van de Laar MJ, Schop WA, et al. Different demographic and sexual correlates for chlamydial infection and gonorrhoea in Rotterdam. Int 7 Epidemio 1997;26:1373-85.

26 Stergarchis A, Scholes D, Heidrich FE et al. Selective screening for Chlamydia trachomatis infection in a primary care population of women. Am ₹ Epidemiol 1993;143-53.

27 Orr P, Sherman E, Blanchard J, et al. Epidemiology of infection due to Chlamydia trachomatis in Manitoba, Canada. tion due to Chlamydia trachom
Clin Infect Dis 1994;19:876-83.

28 Ellen JM, Kohn RP, Bolan GA, et al. Socioeconomic differences in sexually transmitted disease rates among black and white adolescents in San Francisco, 1990 to 1992. Am Public Health 1995;85:1546-8.

29 Burstein GR, Gaydos CA, Deiner-West M, et al. Incident Chlamydia trachomatis infections among inner-city adolescent females. $\mathscr{F} A M A$ 1998;280:521-6.

30 Becker KM, Glass GE, Brathwaite W, et al. Geographic epidemiology of gonorrhoea in Baltimore, Maryland, using a demiology of gonorrhoea in Baltimore, Maryland, using a 709-15.

31 Bhopal R. Is research into ethnicity and health racist, unsound or important science? BMF 1997;314:1751-6.

32 Rankin J, Bhopal R. Current census categories are not a good match for identity. BMF 1999;318:1696.

33 Winter AJ, Sriskandabalan PS, Wade AAH, et al. Sociodemography of first-episode genital warts in Coventry, UK, 1992 to 1996. In: Proceedings of the 13th meeting of the International Society for Sexually Transmitted Diseases Research, Denver 1999 (Abstract 344).

34 Hawker JI, Bakhshi SS, Ali S, et al. Ecological analysis of ethnic differences in relation between tuberculosis and poverty. BMF 1999;319:1031-4. 